\title{
OPEN Author Correction: Development of a diagnostic compatible BCG vaccine against Bovine tuberculosis
}

\begin{abstract}
Aneesh Chandran, Kerstin Williams, Tom Mendum, Graham Stewart, Simon Clark, Sirine Zadi, Faye Lanni, Neil McLeod, Ann Williams, Bernado Villarreal-Ramos, Martin Vordermeier, Veerasamy Maroudam, Aravind Prasad, Neeraj Bharti, Ruma Banerjee, Sunitha Manjari Kasibhatla \& Johnjoe McFadden
\end{abstract}

Correction to: Scientific Reports https://doi.org/10.1038/s41598-019-54108-y, published online 28 November 2019

Faye Lanni was omitted from the author list in the original version of this Article. This has been corrected in the PDF and HTML versions of the Article, and in the accompanying Supplementary Information file.

The Author Contributions section now reads:

A.C. generated the B.C.G. double and triple knock out, carried out the competitions experiments, data analysis and wrote the manuscript; K.W. generated libraries, individual mutants and carried out data analysis; T.M. contributed to the experiments and reviewed the manuscript; GS conceived the project and reviewed the manuscript; S.C., S.Z., N.M., F.L. \& A.W. carried out the Guinea pig experiment; B.V.R. reviewed the manuscript; M.V. conceived the project and reviewed the manuscript; V.M. prepared antigen cocktail for skin test; A.P., N.B., R.B., S.M.K. carried out TRANSIT analysis; JM conceived the project and reviewed the manuscript. All authors read and approved the final manuscript.

(i) Open Access This article is licensed under a Creative Commons Attribution 4.0 International License, which permits use, sharing, adaptation, distribution and reproduction in any medium or format, as long as you give appropriate credit to the original author(s) and the source, provide a link to the Creative Commons licence, and indicate if changes were made. The images or other third party material in this article are included in the article's Creative Commons licence, unless indicated otherwise in a credit line to the material. If material is not included in the article's Creative Commons licence and your intended use is not permitted by statutory regulation or exceeds the permitted use, you will need to obtain permission directly from the copyright holder. To view a copy of this licence, visit http://creativecommons.org/licenses/by/4.0/.

(c) The Author(s) 2020 